
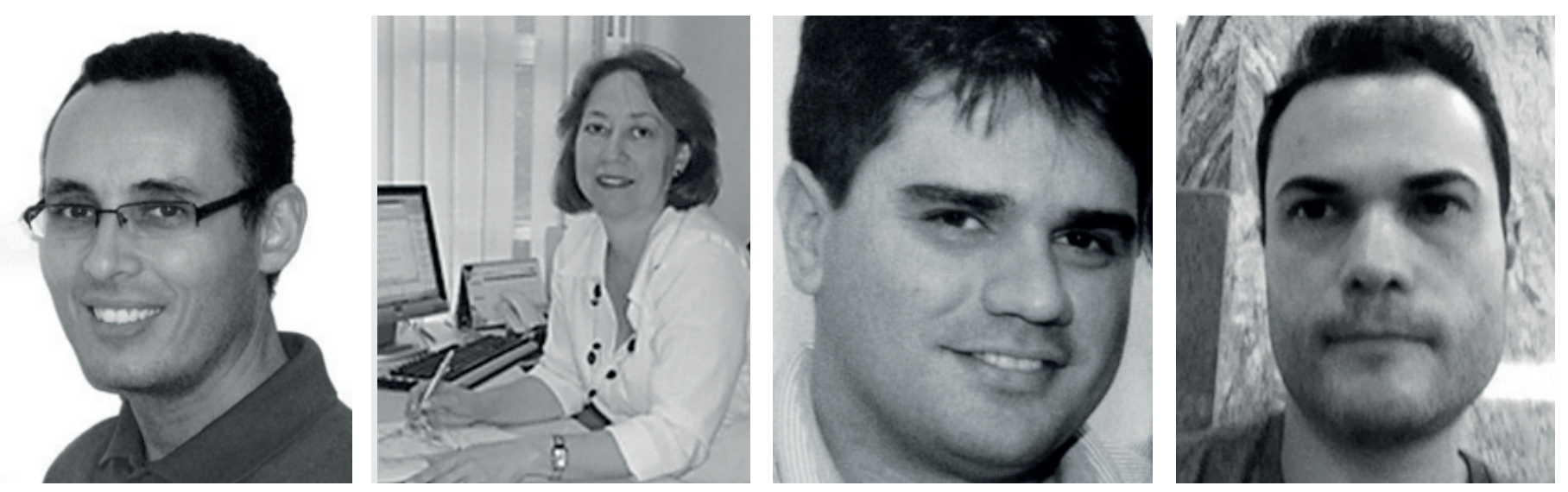

\title{
Cristiano alVes
}

Dr.; Universidade Federal do Rio Grande do Norte

cralves@dcdesign.com.br

\section{SUSIE MACEDO}

Ma.; SENAI/ FIERN

GILENO NEGREIROS

Me.; SENAI/FIERN

gilenonegreiros@rn.senai.br

\section{KILDER RIBEIRO}

Dr.; Universidade Federal do Rio Grande do Norte kildercesar@gmail.com

susie@rn.senai.br

\section{INTEGRATING STRATEGIC AND}

SUSTAINABLE DESIGN APPROACH

FOR INNOVATION PROCESS: A

\section{CEMENT CASE STUDY}

\section{INTEGRANDO ABORDAGENS DE DESIGN ESTRATÉGICO E SUSTENTÁVEL PARA O PROCESSO DE INOVAÇÃO: O CIMENTO COMO ESTUdO DE CASO}

RESUMO

A sociedade global e da tecnologia mudaram as relações de mercado. Qualidade e custo não são mais os principais aspectos de qualquer produto 
industrial. Por outro lado, design, inovação e sustentabilidade tornaram-se requisitos significantes para a competitividade da empresa.Neste contexto, a abordagem de design tem mostrado evoluções, integrando aspectos sociais e ambientais além dos aspectos tradicionais, como técnica e economia. Ainda assim, o design tem se tornando uma oportunidade estratégica para as empresas, melhorando a sua competitividade e aumentando a sua quota de mercado. Assim, esta pesquisa analisou a integração do Design Sustentável e do Coaching de Design Estratégico (SDC) nas atividades de tomada de decisão das empresas. A empresa de cimento (BQMIL) foi designada como estudo de caso, no qual os resultados anteriores apontaram a lacuna significativa desses conceitos para gerar Eco-Inovação e Eco-Brand para aumentar a sua quota de mercado, corroborando a expectativa da equipe de projeto.

\section{PALAVRAS CHAVE}

Design estratégico. Design sustentável. Marca sustentável.

\section{ABSTRACT}

Global societyand technology havechanged therelationships of themarket. Quality and cost are not the main aspects of any industrial product. On the other hand, design, innovation and sustainability became significant requirements to company's competitiveness. In this context, the design approach has shown evolutions, integrating social and environmental aspects beside traditional aspects such as technical and economic. Still, design has been becoming a strategic opportunity for companies, improving their competitiveness and increasing their market share. Thus, this research has analyzed the integration of both the Sustainable Design and Strategic Design Coaching (SDC) method in the making decision activities of companies. A cement company (BQMIL) was assigned as case study, in which the previous results have pointed out the significant hole of those concepts to generate Eco-innovation and Eco-Brand to increase its market share, corroborating the expectative of the design team.

\section{KEYWORDS}

Strategic Design. Sustainable Design. Sustainable Brand. 


\section{DESIGN AND INNOVATION: SIGNIFICANT SUBJECTS}

Design and innovation are complementary processes, in which interactions and synergies have the main objective to change the culture and material basis of societies (BENAVIDES, 1999). In this context, design and innovation have several common factors, both deal with multidisciplinary activities that are inherent in the design process, such as: planning, creativity, technology, experiments, production processes and market. All of these activities are forward-looking and therefore are agents of social changes. Thus, design becomes a significant part of the innovation process, leading concepts and inventions to the market. Therefore, in the synergistic and dynamic context of innovation, design must be considered from its significant aspect as a tool for promoting quality and technology in the product development, an essential part of technological advancement (BENAVIDES, 1999).

According Bonsiepe (1997), design, technology and science are decisive factors for innovation process. Design appears as link between of different knowledge areas and promotes the integration of innovation in the everyday life. When integrated with institutes of scientific and technological research, the design is an important factor for innovation and competitiveness (RANGEL, 2008). In this sense, to establish an effective process of excellence in innovation, it is important the interaction among design, technology and science. So, the consolidation of the design approach in business and social culture of Rio Grande do Norte has huge potential in improve the development of the state in economic, technical and environmental aspects.

Conceptually, there are several aspects that emerge from innovation process defining new paths to be adopted by different demands, in which the design is presented as an important driver, since the decision-making process of development until the release of a product (or service) in the market inferring and optimizing the innovation process in different aspects of the project (DAGNINO, 2004; SILVA, EGLER, 2004, SEBRAE, 2005). Design emerges as an activity in which ideas or market requirements are information (data) to specify a physical form, from conceptual sketches to detailed specifications (BENAVIDES, 1999). Nowadays design is embedded in the daily life of societies, making it essential for the success of products. According survey developed by the National Confederation of Industries (CNI) in Brazil, the design implies 
many benefits for companies, such as: improve institutional image, optimize costs, increase competitiveness and hence exports. Still, each dollar invested in design, mean five dollars in outcome (RAULIK, 2003).

Since the design operates from the decision-making process of development until the launch of a product (or service), it is essential to generate new solutions or in other words, to generate innovation (DAGNINO, 2004; SILVA; EGLER, 2004) optimizing different aspects of the project (Figure 01).

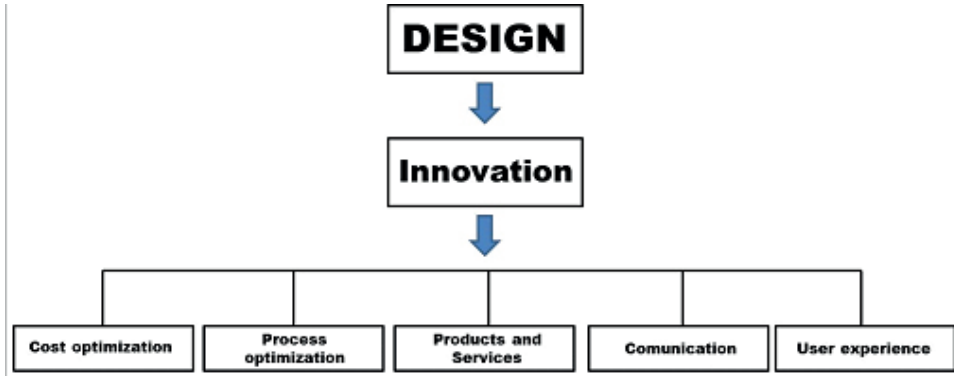

Figure 01 - Design and innovation. (Adapted DAGNINO, 2004)

Design is much more than style. While style is only related to the appearance of the product, which can be wonderful but it does not mean good performance, the design affects the usefulness of the product and its entire life cycle. From a marketing viewpoint, design is how a company turns different its products, attracting the attention of consumers, improving the performance of products and reducing the costs (SEBRAE, 2005).

Design contributes with both tangible and intangible values of companies, either by designing your brand, product development, production feasibility, understanding the user needs and their perceptions regarding to the product attributes, among other aspects. The design scope is from conception, through different stages, to deliver the outcome to the customer (Figure 02).

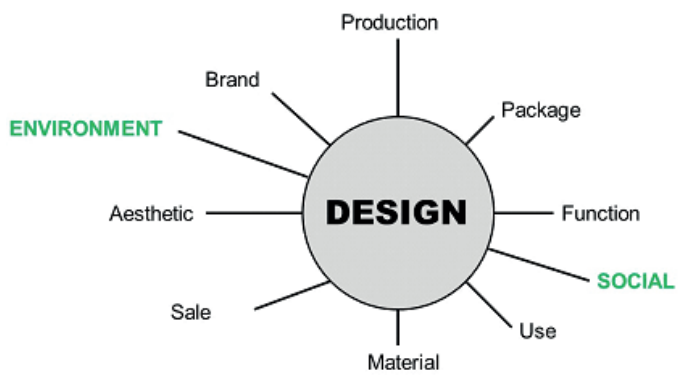

Figure 02 - Design scope. 
Design transcends the development of products as isolated objects, it has been consolidating as a management process. Based on the possible contribution of Design, figure 03 shows the levels of design in companies.

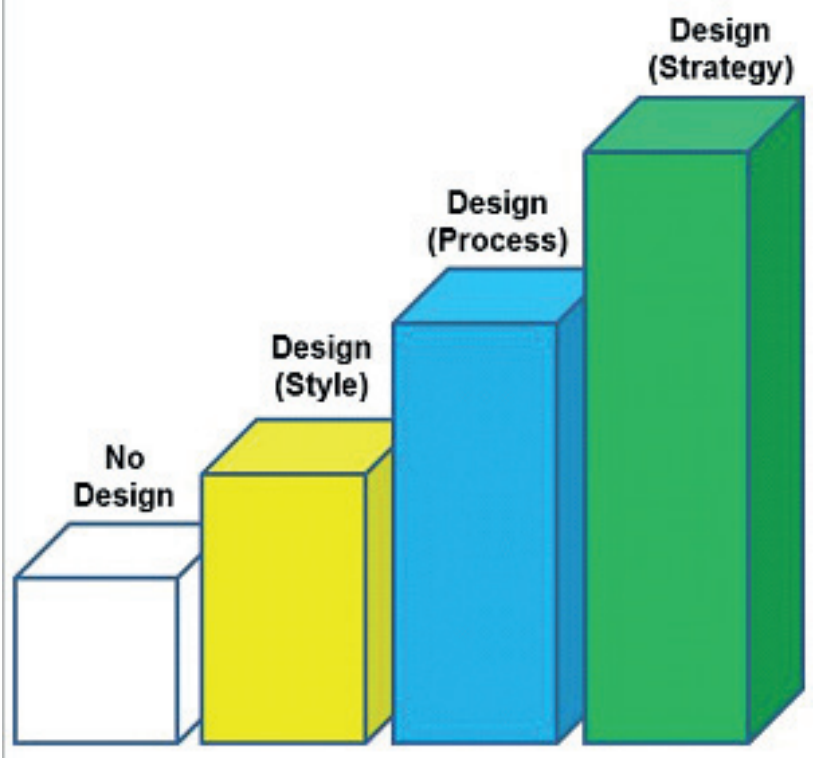

Figure 03 - Different levels of design.

- Level 1: companies that do not know design or have a department that is in charge of introducing functional and aesthetics aspects in the product development process;

- Level 2: companies that consider design as style, introducing it at advanced stages of the project, as a finishing detail;

- Level 3: companies that know and dominate the design process. Design is integrated with marketing, engineering and other areas of the company;

- Level 4: companies that incorporate design in their strategies stimulating and promoting innovation.

However, the design must be aware of their environmental responsibility, using their tools and techniques for the development of products that aim innovation and sustainability to improving the quality of life of society (DAGNINO, 2004). In this context, as innovation and competitiveness strategy, the design has brought an evolution in its approaches, following technological and social evolution over the years. Thus, it has been specializing in take into account environmental aspects in the projects, which mean changing attitudes and goals, raising the Sustainable Design. 


\subsection{SUSTAINABLE DESIGN: NEW INTEGRATED APPROACH OF PROJECT}

Sustainable Design has been considered an evolution of the innovation process using multidisciplinary approaches of design in the development of products whose objectives take into consideration environmental variables of the project, besides the traditional technical and economic variables [9]. These new variables aim to reduce the negative social and environmental impacts raised by projects and/or products from industrial activities.

The main focus of the Sustainable Design is the citizen and environment, to achieve this objective it is fully participatory approach, then all members of the group are considered as thinking in decision-making processes, than a basic workforce (WEBER, 2004). In Sustainable Design process, the group is responsible for the impacts raised on the entire life-cycle of the product and/or process (Figure 04).

\section{Environmental aspects SUSTAINABLE DESIGN}

Social aspects
Collaborative team

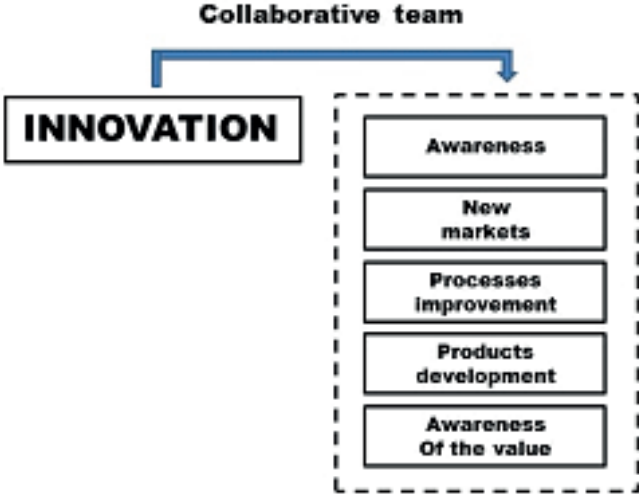

Figure 04 - Sustainable Design and collaborative chain. (Adapted DAGNINO, 2004)

In this collective decision-making process, it is necessary to keep the project coherent with the three aspects of Sustainable Design, well known as "Triple Bottom Line" (Figure 05), taking into account the entire life cycle of the products (ALVES, 2010).

- Social aspect (people), considered as significant requirement in all stages of the product life-cycle;

- Environmental aspect, reducing still in project phase the negative impacts of products, addressing such impacts preventively;

- Economic aspect, providing economic viability of the product, aiming the planning and sustainability of the business. 


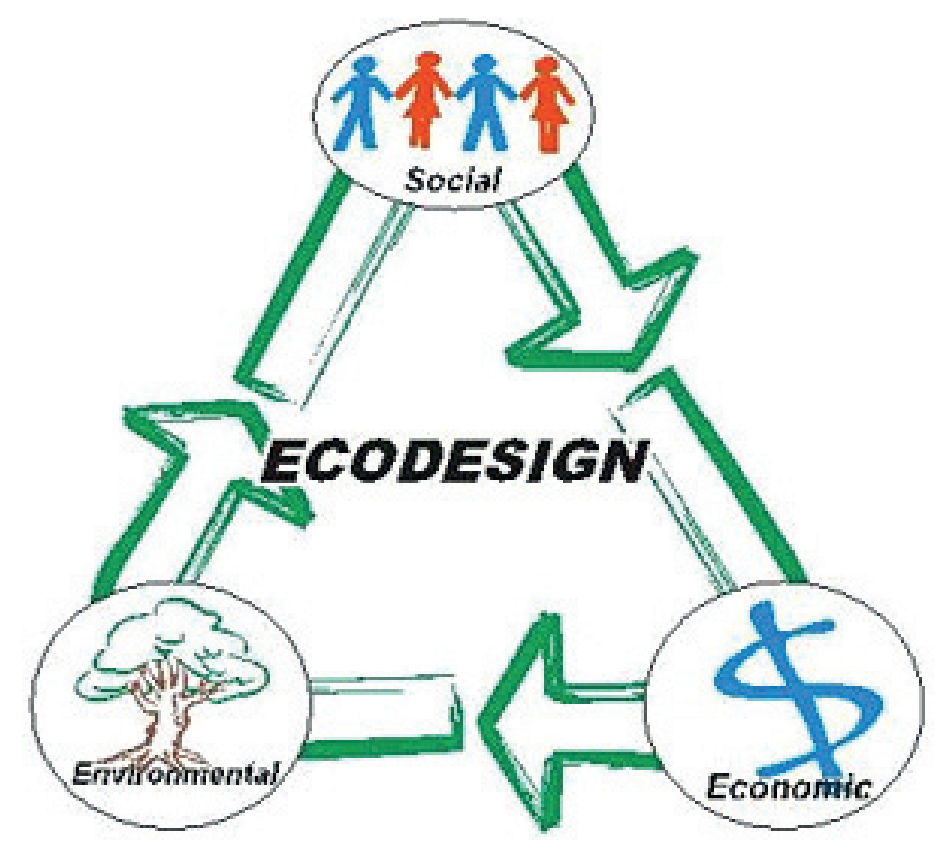

Figure 05 - Triple Bottom Line. (ALVES, 2010).

Sustainable Design integrates all stakeholders in the decision-making processes related to the Triple Bottom Line, sharing responsibilities and benefits among them. In general, the concept of Sustainable Design promotes the link between the design activity and environment, oriented by environmental criteria, unlike the traditional aspects considered by Design. Thus, sustainable design takes a systemic approach to find the sources of impacts and increase the eco-efficiency of products still in the design phase (MANZINI, VEZZOLI, 2002).

Although the design phase is a "clean" phase, it defines most of environmental impacts, in fact, according some researches the environmental impacts of most products (about 90\%), are determined still in design phase (LEÃO, 2003). Therefore, the main advantage of sustainable design is to consider environmental issues in early stages of the project. For instance, a survey developed in Netherlands suggests that the design process can reduce about $25 \%$ to $50 \%$ both the pollution levels and resource consumption per product (HEMMEL, 1997).

Sustainable Design acts as a means of system innovation for sustainability (Gaziulusoy, Boyle, and McDowall 2013). Interventions that aim a lower environmental impact, higher product value and utility are most effective during the product design stage. In parallel to the shortened 
product lifecycles and competition, companies are forced to increase the flexibility and responsiveness of their product design and manufacturing operations. As a result, firms have understanding of how to identify and capitalize on opportunities for consistent, sustainability-driven revenue growth and brand value in both local and global markets.

Indeed, one of the most competitive advantages of eco-innovation for business strategies are regarding to the cost and product differentiation, increasing the value of intangible assets (branding). Today's customers buy greener products, services or technologies because they work better, save money or enhance health. Eco-brands integrate relevant environmental benefits into products alongside cost and quality and communicate evidencebased messages avoiding "green washing". Costumers have started to shift spending to greener brands within a category, purchasing from companies with a brand that is perceived as green, regardless of whether or not the product that they ultimately purchase is one of the company's "green" products.

Implications of Green Branding are widely known and the emerging green consumer purchase behavior suggests the following scenario. Then, plenty of new companies are starting out as a "green" brand; older companies want to re-brand their products to be more eco-friendly. Those companies that do not "go green", risk being branded socially irresponsible, making them vulnerable to criticism and brands at risk. In this sense, sustainable design has also shown many benefits in terms of sales and market share of companies, since eco-innovations raise their environmental image that is appreciated by consumers, and improves the company's competitiveness (HEMMEL, 1997).

\section{OBJECTIVE}

The goal of this research is analyze the influence of both Sustainable Design concepts and Strategic Design Coaching on the innovation, hence on the competitiveness companies through a case study (BQMIL). Still, the study intends to assess how environmental aspects imply on company brand and on its competitiveness.

\section{CASE STUDY: BUILDING MARKET}

This case study has been analyzing a cement company (BQMIL), 
which is one of the most important cement company in Rio Grande do Norte (Brazil), employing about 150 people and with a volume production of about 12,000 tons per month. The study has been showing how environmental approach is fundamental to achieve innovation requirements, considering that most people are more willing to believe and buy greener products (CNI, 1998, FIERN, 2012). It also has showing how sustainable design concepts can motivate changes and improvements in products and processes.

To achieve the goals of the project, the Strategic Design Coaching (SDC) has performed (SENAI, 2013). SDC is a method developed by SENAI Brazil which intends to integrate design approach in the company's management, promoting innovations in products and/or processes and improving their competitiveness. SDC consists of four main phases such as: Check-Up, Analysis, Strategy and Implementation. It is important to note that currently the project has been developing, thus discussions are based on previous results from Check-Up phase (Figure 06).

\section{CHECK-UP}

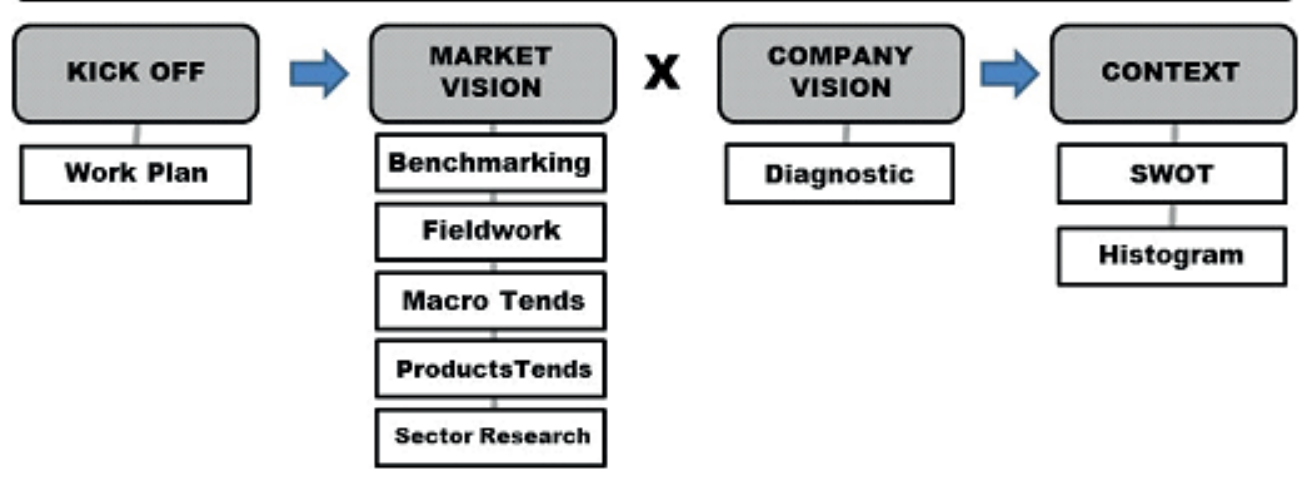

Figure 06 - Strategic Design Coaching (SDC): Check-Up phase.

For the research, four cement companies were analyzed and compared with BQMIL related to their Marketing/Brand, Products and Logistic. Concurrent 1 and 2 are big companies and concurrent 3 and 4 are SMEs. The survey was performed by a questionnaire focused on their bigger customers and sales agents (35 customers/agents). Figure 07 illustrates the previous results of the survey. 


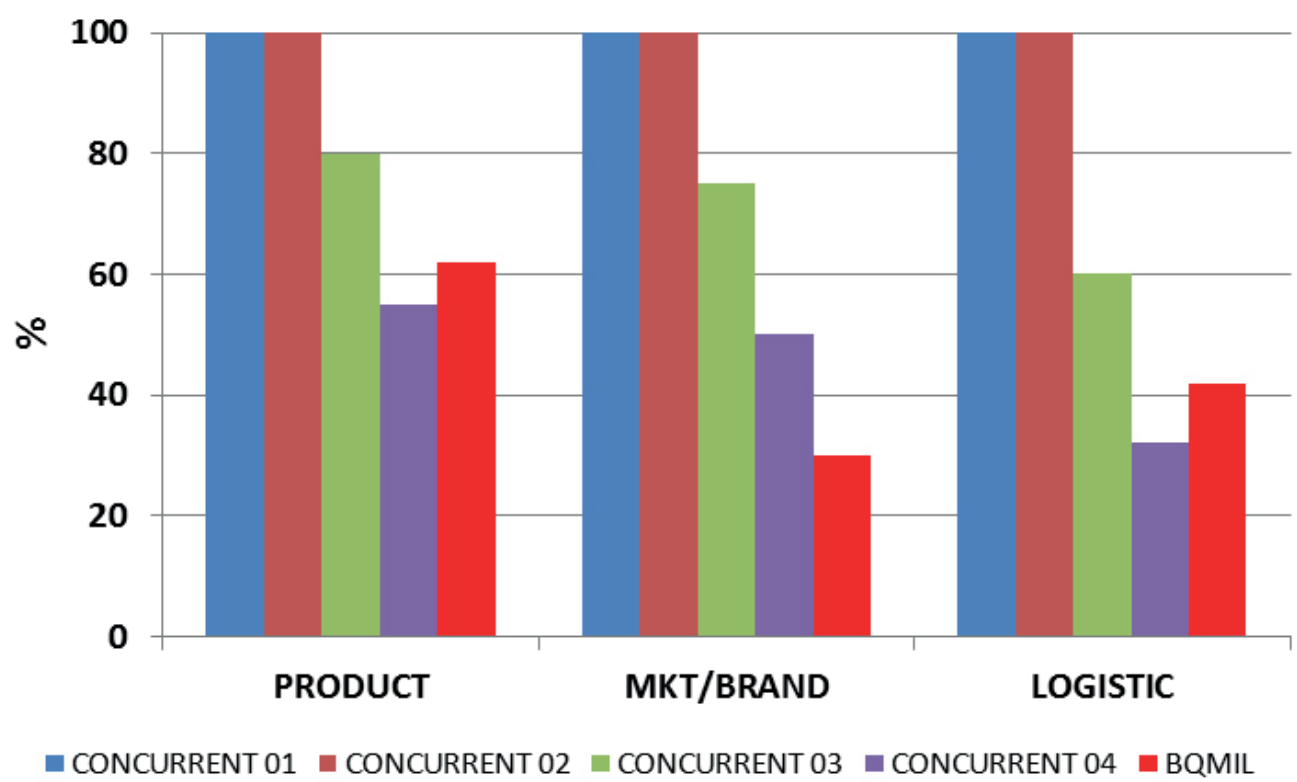

Figure 07 - Case study concurrent.

Results show that BQMIL place a week market position compared to concurrent. Product, as a tangible aspect, is the only one in which the most respondents assigned good performance of company (about 62\%). However, intangible aspects such as Marketing/Brand and Logistic, just about $30 \%-40 \%$ of respondents, respectively, pointed out BQMIL as a good company. It shows the week institutional image of company and its poor strategic development, since it perceives just tangible aspects as its products.

Regarding specifically to Brand and Sustainability aspects, the results show that when asked about how important they are for building companies, most of respondents (about $73 \%$ and $64 \%$ respectively) consider them as significant (Figure 08). It is possible to note that, nowadays, environmental issues are important requirements for cement companies, since they have their image as dirty companies. In this context, the strategic and embracing approach of SDC integrated with sustainable design concepts clarified that the development of a friendly image for BQMIL, can improve its competitiveness, increasing the market share. Still, both bigger analyzed companies attach their institutional brand as environmental friendly. This approach corroborates with the results. 


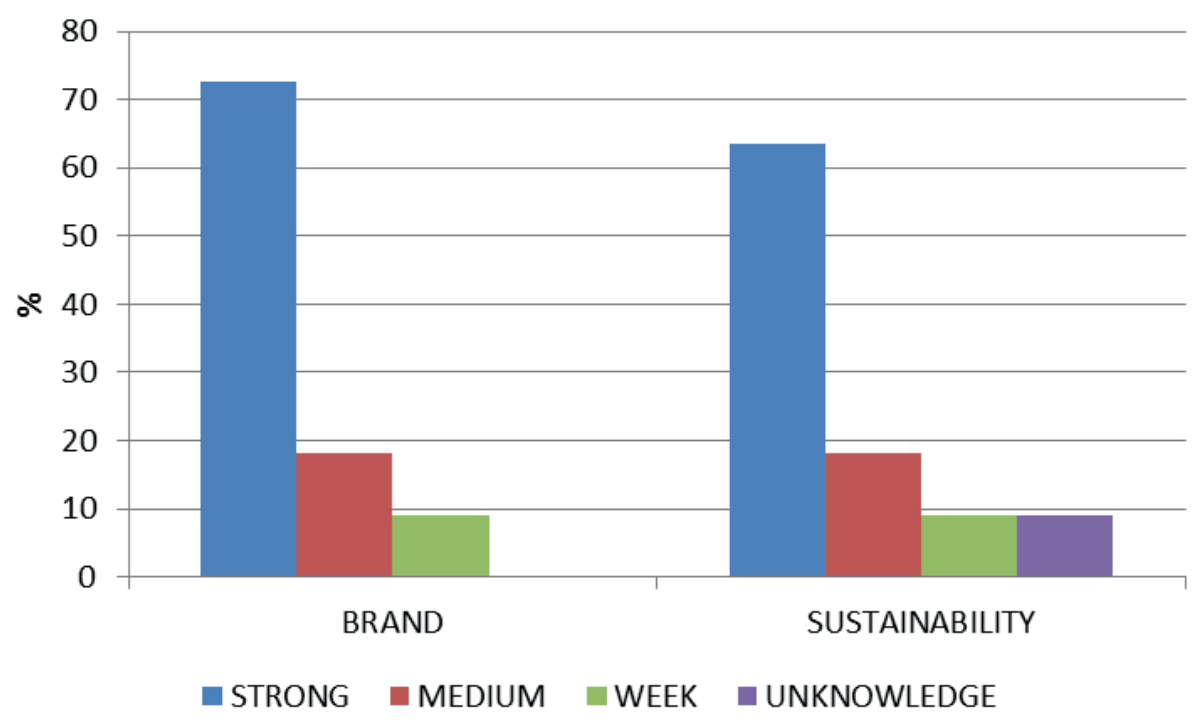

Figure 08 - Significant aspects for building companies.

Based on previous results, the design team has developed strategies to improve the competitiveness of the case study company (BQMIL). Still, the results provided significant data which will be able to be take into account in make decision activities.

\section{CONCLUSIONS}

Several factors can be shared by design and innovation process to increase the competitiveness of companies. Nowadays, in which more and more companies invest in developing new methods and technologies that address the environmental variable in their strategies, Sustainable Design concepts become a significant factor to provide eco-innovation, improving their market share. It leads concepts and inventions to the market, bringing up a perceived environmental value for brands. In this context, this research has been pointed out how significant is the integration between Sustainable Design concepts and Strategic Design Coaching method to develop ecoinnovations and mainly, an eco-institutional image for companies. Still, the case study has been demonstrating to design team how integrate the design culture in SMEs, increasing their competitiveness and collaborating with their make decision phase. Finally, thanks the results, important aspects were revealed providing data to be optimized by company.

\section{REFERENCES}


ALVES, C. Sustainable Design through jute fiber composite. Ed. Saarbrücken: LAP LAMBERT Academic Publishing GmbH \& Co. KG, 2010.

BENAVIDES, Puerto H. Design e Inovação Tecnológica. Coletâneas de ideias para construir um discurso. Salvador: Ed. IEL - FIEB, 1999.

BONSIEPE, Gui. Do material ao digital. Florianópolis: FIESC/IEL, 1997.

CONFEDERAÇÃO NACIONAL DA INDÚSTRIA. A Importância do Design para sua Empresa. Brasília: CNI, 1998.

COSTA, Mario B. Contribuições do design social. SIMPÓSIO BRASILEIRO DE DESIGN SUSTENTÁVEL, 2., 2008, São Paulo, Anais... São Paulo: Universidade Anhembi Morumbi, 2008.

DAGNINO, R. A tecnologia social e seus desafios. In: PAULO, A. (Ed.). Tecnologia social: uma estratégia para o desenvolvimento. Rio de Janeiro: Fundação Banco do Brasil, 2004. Disponível em: <http://www.oei.es/salactsi/Teconologiasocial. pdf $>$. Acesso em: 25 de abril de 2014.

FEDERAÇÃO DAS INDÚSTRIAS DO ESTADO DO RIO GRANDE DO NORTE. Indicadores básicos e indústria. Natal: FIERN, 2012.

HEMEL, C. The IC Ecodesign project: results and lessons from a Ducth initiative to implement ecodesign in small and medium-sized companies. The Journal Sustainable Product Design, Dordrecht, v. 2, 1997. p.7-19.

LEÃO, A. L. (Org.). Primeiro Convênio IST-Lisboa . Botucatu: Unesp, 2003.

MANZINI, E; VEZZOLI, C. O desenvolvimento de produtos sustentáveis. São Paulo: EDUSP, 2002.

PAULO, A. (Ed.). Tecnologia social: uma estratégia para o desenvolvimento. Rio de Janeiro: Fundação Banco do Brasil, 2004.

RANGEL, Marcia M. Design, tecnologia e ciência: os três campos que efetivam a inovação. In: CONGRESSO BRASILEIRO DE PESQUISA E DESENVOLVIMENTO EM DESIGN, 8., 2008, São Paulo. Anais... São Paulo: Centro Universitário Senac, 2008.

RAULIK, G. Models for Design Advisory Service: the rapport between design organisations and SMEs. Master Dissertation in Design Strategy and Innovation. Design Strategy and Innovation Program, Brunel University, United Kingdom, 2003.

SEBRAE. Boletim Estatístico de Micro e Pequenas Empresas. Brasília: SEBRAE, 2005.

SERVIÇO NACIONAL DE APRENDIZAGEM INDUSTRIAL. Design Estratégico

Coaching. Material de consultoria. Curitiba: SENAl, 2013.

Recebido em: 05/03/2014;

Aceito em: 12/03/2014.

Esta obra foi licenciada com uma Licença Creative Commons.
SILVA, V. P. e EGLER, C. A inovação em tempos de globalização: uma aproximação. Scripta Nova Revista electrónica de geografía y ciencias sociales, Barcelona: Universidad de Barcelona, vol. 8, núm. 170, 2004.

WEBER, Max. A ética protestante e o espírito do capitalismo. São Paulo: Martin Claret, 2004. 